(C) 2021, The Authors. Published by Elsevier Inc. and Fass Inc. on behalf of the American Dairy Science Association ${ }^{\circledR}$. This is an open access article under the CC BY-NC-ND license (http://creativecommons.org/licenses/by-nc-nd/4.0/).

\title{
Genotype by climate zone interactions for fertility, somatic cell score, and production in Iranian Holsteins
}

\author{
Farzad Atrian-Afiani, ${ }^{1,2}$ Hongding Gao, ${ }^{2}$ Sahereh Joezy-Shekalgorabi, ${ }^{3}$ Per Madsen, ${ }^{2}$ Mehdi Aminafshar, ${ }^{1}$ \\ Sadeghi Ali, ${ }^{1}$ and Just Jensen ${ }^{2 *}$ \\ ${ }^{1}$ Department of Animal Science, Science and Research Branch, Islamic Azad University, Tehran, 1477893855, Iran \\ ${ }^{2}$ Center for Quantitative Genetic and Genomics, Aarhus University, 8830 Tjele, Denmark \\ ${ }^{3}$ Department of Animal Science, Shahr-e-Qods Branch, Islamic Azad University, Tehran, 37515-374, Iran
}

\begin{abstract}
The objective of this study was to investigate genetic variation and genotype by environment $(\mathrm{G} \times \mathrm{E})$ interactions for fertility (including age at first calving and calving interval), somatic cell score (SCS), and milk production traits for Iranian Holsteins. Different environments were defined based on the climatic zones (cold, semi-cold, and moderate) and considering the herd location. Data were collected between 2003 and 2018 by the National Animal Breeding Center of Iran (Karaj). Variance and covariance components and genetic correlations were estimated using 2 different models, which were analyzed using Bayesian methods. For both models, performance of traits in each climate were considered as different traits. Fertility traits were analyzed using a trivariate model. Furthermore, SCS and production traits were analyzed using trivariate random regression models (records in different climate zones considered as different traits). For the fertility traits, the largest estimates of heritability were observed in cold climate. Fertility performance was always better in cold environment. Genetic correlations between climatic zones ranged from 0.85 to 0.94 . For daily measurements of SCS and production traits, heritability ranged from 0.031 to 0.037 and 0.069 to 0.209 , respectively. Genetic variances were the highest in the semi-cold and moderate climates for the SCS and production traits, respectively. Furthermore, across the studied climates, 305-d genetic correlation ranged from 0.756 to 0.884 for SCS and from 0.925 to 0.957 for the production traits. The structure of genetic correlation within each climate indicated a negative correlation between early and late lactation for SCS, especially in the cold climate and for milk production in the moderate
\end{abstract}

Received December 23, 2020.

Accepted July 14, 2021.

*Corresponding author: Just.Jensen@qgg.au.dk climate. For fat percentage, in all climatic zones, the lowest genetic correlations were observed between early and mid-lactation. In addition, for protein production in the cold climate, a negative correlation was observed between early and late lactation. Results indicated heterogeneous variance components for all the studied traits across various climatic zones. Estimated genetic correlations for SCS revealed that the genetic expression of animals may vary by climatic zone. Results indicated the existence of $\mathrm{G} \times \mathrm{E}$ interaction due to the climatic condition, only for SCS. Therefore, in Iranian Holsteins, the effect of $\mathrm{G} \times \mathrm{E}$ interactions should not be neglected, especially for SCS, as different sires might be optimal for use in different climatic zones.

Key words: $(\mathrm{G} \times \mathrm{E})$ interactions, fertility, SCS, production, climatic condition

\section{INTRODUCTION}

The expansion of the Holstein population in Iran began with the imports of Holstein heifers from Europe, the United States, and Canada in the 1970s and early 1980s. The Iranian Holstein breed was developed by the Iranian livestock improvement organization, called the Animal Breeding Center (Dadpasand et al., 2008), with the purpose of rapidly increasing milk yield. To ensure this, semen was imported from foreign countries, especially from the United States (Ghiasi et al., 2011). However, germplasms have been imported without attention to the possible consequences of genotype by environment interactions $(\mathbf{G} \times \mathbf{E})$, and these interactions may lead to different rankings of the same genotype in different climates or management systems (Villalobos et al., 2001). In varying environments, the phenotypic expression of any specific genotype could change, which is known as phenotypic plasticity or environmental sensitivity (Falconer and Mackay, 1996). The existence of $\mathrm{G} \times \mathrm{E}$ has been well documented for production traits in many studies. For instance, $\mathrm{G} \times \mathrm{E}$ for milk yield in Holsteins was demonstrated across arid, semi-humid, 
and humid climates in Mexico (Valencia et al., 2008). Also, low genetic correlations for the 305-d milk yield, based on the common sires between Luxembourg and Tunisian Holsteins, indicated the existence of genotype by environmental interaction, which suggests different ranking of sires in these countries (Hammami et al., 2008). A G $\times$ E interaction has also been found when comparing genotypes at different levels of temperaturehumidity index (THI) as a method to quantify sensitivity to heat stress (Ravagnolo and Misztal, 2000; Hayes et al., 2003). Santana Jr. et al. (2019) demonstrated that $\mathrm{G} \times \mathrm{E}$ interaction due to heat stress can influence test-day milk yield. They suggested that new strategies should be considered to mitigate the negative effects of heat stress on milk production. Bouraoui et al. (2002) and Lambertz et al. (2014) studied the effects of THI on milk production and SCS in different housing systems (for cows with or without having access to grazing) and found that heat stress can decrease the level of production in all systems and leads to greater SCS when THI was more than 65 .

Fertility traits in dairy cows are very sensitive to environmental factors such as season (or month), especially in hot climates (Ismael et al., 2016; Rahbar et al., 2016). For example, conception rate of Holsteins in New York during colder months (December to April) was reported at approximately $55 \%$, whereas during the summertime the rate was reduced by up to $10 \%$ (Huang et al., 2008). Furthermore, days open in firstand second-parity Holsteins were greater in the summer months (March to June; Boonkum et al., 2011). The existence of $\mathrm{G} \times \mathrm{E}$ changed the ranking of Holstein sires for age at first calving between Brazil and Colombia (Cerón-Muñoz et al., 2004). Also, significant $\mathrm{G} \times \mathrm{E}$ effects were found for calving interval between Mexico and Canada (Montaldo et al., 2017).

In many studies, random regression models (RRM) have been used for the analyzing longitudinal data collected at regular intervals (Schaeffer, 2004). Such RRM have many advantages, including more accurate estimation of genetic and environmental effects at different stages of lactation (Jensen, 2001). In addition, RRM can be used for multiple-trait analysis, in which a trait measured under different environmental conditions would be considered as different traits. In this case, genetic correlation between 2 environments can be used for the evaluation of $\mathrm{G} \times \mathrm{E}$.

In previous studies in Iranian Holsteins, mainly the $\mathrm{G} \times \mathrm{E}$ of production traits across geographical regions has been investigated (Bohlouli et al., 2014). The milk pricing system in Iran is based mainly on milk volume and fat percentage (and to some extent protein percentage). Therefore, we included these production traits in our study. To our knowledge, no estimation of genetic correlation between different climates or within climates for SCS and fertility traits has been performed for Iranian Holsteins. Therefore, the aims of this study were to estimate the genetic parameters and the amount of $\mathrm{G} \times \mathrm{E}$ for fertility, production, and SCS under different climatic conditions in Iranian Holsteins.

\section{MATERIALS AND METHODS}

\section{Data}

The Iranian dairy cattle population comprises about 800,000 purebred Holstein cows plus several minor domestic breeds (Hossein-Zadeh et al., 2008). In this study, single records of the age at first calving (AFC) and calving interval (CInt) traits, and longitudinal data of SCS and production traits (including milk yield, in kilograms, and fat and protein percentages) in first-lactation Holstein cows were used. Data were collected by the National Animal Breeding Center of Iran (Karaj), during March 2003 and January 2018. Individual SCC records were transformed into SCS thus: $\mathrm{SCS}=\log _{2}(\mathrm{SCC} / 100,000)+3$. Test-day records of milk yield and fat and protein were edited to be within 3 to $75 \mathrm{~kg}, 0.03$ to $5.553 \%$, and 0.03 to $4.5123 \%$, respectively. The test days ranged from 6 to 305 DIM. For SCS and production traits, cows with at least 2 valid monthly test-day records were included in the analyses. In addition, the first monthly test had to be recorded before 90 DIM to be considered in the analyses. Also, the difference between any 2 subsequent test-day records had to be greater than $15 \mathrm{~d}$. The number of cows per herd were required to be more than 150 over the whole study period, and the number of first-lactation cows per herdyear of calving was required to be at least 10. After editing, the total number of first-lactation cows included in the analysis were 260,962 and 181,093 for AFC and CInt, and 260,962, 260,829, 259,582, and 259,634 for SCS, milk yield, fat, and protein, respectively. Pedigree was traced back as far as possible, to maximize genetic connections between climate zones. Ultimately, the pedigree included 275,103 dams and 7,301 sires, with birth years from 1950 to 2016. Records were divided into 3 climatic zones, including cold, semi-cold, and moderate, considering the herds' locations. Climates were specified based on synoptic station data (Bohlouli et al., 2014). Table 1 presents the number of records for AFC, CInt, SCS, milk yield, fat, and protein, as well as the climatic information of the studied zones.

\section{Statistical Models}

For each fertility trait (i.e., AFC and CInt) variance and covariance components were estimated using a tri- 
Table 1. Descriptive statistics of the data set for each trait across climatic zones

\begin{tabular}{|c|c|c|c|c|}
\hline Description $^{1}$ & \multicolumn{3}{|c|}{ Climate zone $^{2}$} & Total \\
\hline Average temperature $\left({ }^{\circ} \mathrm{C}\right)$ & 16.1 & 13.5 & 11.0 & - \\
\hline Minimum temperature $\left({ }^{\circ} \mathrm{C}\right)$ & 2.9 & 0.0 & -3.0 & - \\
\hline Area $(\%)$ & 21.2 & 12.9 & 13.2 & 47.3 \\
\hline Number of herds & 77 & 63 & 25 & 165 \\
\hline $\mathrm{AFC}$ & 105,087 & 115,145 & 40,730 & 260,962 \\
\hline CInt & 74,253 & 78,611 & 28,229 & 181,093 \\
\hline SCS & 733,391 & 866,902 & 298,494 & $1,898,787$ \\
\hline Milk & 729,032 & 857,689 & 296,620 & $1,883,541$ \\
\hline Fat & 691,952 & 852,015 & 296,079 & $1,840,046$ \\
\hline Protein & 694,498 & 851,894 & 296,010 & $1,842,402$ \\
\hline \multicolumn{5}{|l|}{ Mean (SD) } \\
\hline Protein (\%) & $3.008(0.372)$ & $3.053(0.349)$ & $3.111(0.378)$ & $2.959(0.621)$ \\
\hline
\end{tabular}

${ }^{1} \mathrm{AFC}=$ age at first calving; CInt $=$ calving interval.

${ }^{2}$ Geographical conditions in Iran grouped into 6 climate zones (very warm, warm, moderate, semi-cold, cold, and very cold). In this study we had access to 3 regions, which covered about $47.3 \%$ of the area of Iran.

variate animal model. Fertility records in each climate were considered as different traits using the following model:

$$
\left[\begin{array}{l}
\mathbf{y}_{1} \\
\mathbf{y}_{2} \\
\mathbf{y}_{3}
\end{array}\right]=\left[\begin{array}{ccc}
\mathbf{X}_{1} & 0 & 0 \\
0 & \mathbf{X}_{2} & 0 \\
0 & 0 & \mathbf{X}_{3}
\end{array}\right]\left[\begin{array}{l}
\mathbf{b}_{1} \\
\mathbf{b}_{2} \\
\mathbf{b}_{3}
\end{array}\right]+\left[\begin{array}{ccc}
\mathbf{Z}_{\mathrm{a} 1} & 0 & 0 \\
0 & \mathbf{Z}_{\mathbf{a} 2} & 0 \\
0 & 0 & \mathbf{Z}_{\mathbf{a} 3}
\end{array}\right]\left[\begin{array}{l}
\mathbf{a}_{1} \\
\mathbf{a}_{2} \\
\mathbf{a}_{3}
\end{array}\right]+\left[\begin{array}{l}
\mathbf{e}_{1} \\
\mathbf{e}_{2} \\
\mathbf{e}_{3}
\end{array}\right],
$$

where $\mathbf{y}_{\mathrm{i}}$ is the vector of observations in the ith climate zone, $i \in(1,2,3)$; $\mathbf{b}_{\mathbf{i}}$ is the vector of fixed effects of herd-year season in the ith climate zone. Seasons were defined as follows: spring from March 21 to June 21; summer from June 22 to September 22; fall from September 23 to December 21; and winter from December 22 to March 20. $\mathbf{a}_{\mathrm{i}}$ is the vector of the additive genetic effects in the ith climatic zone; $\mathbf{e}_{i}$ was the vector of residual effects in the ith climatic zone. Finally, $\mathbf{X}_{\mathrm{i}}$ and $\mathbf{Z}_{\mathrm{ai}}$ were the incidence matrices connecting $\mathbf{b}_{\mathrm{i}}$ and $\mathbf{a}_{\mathrm{i}}$ to $\mathbf{y}_{\mathrm{i}}$. The choice of fixed effects to be considered was made after testing the effects with GLM procedure in the $\mathrm{lm}$ package in $\mathrm{R}$ programming (https://www.r -project.org/). The effects were determined to be statistically significant if $P<0.05$. For model [1], a Bayesian approach using Gibbs sampling was used to obtain posterior distribution for all the model parameters. The sampler implemented used a block updating scheme, with blocks defined by levels of fixed and random effects, to account for correlated traits.
Prior distributions for the breeding values and the residuals were as follows:

$$
\left[\begin{array}{c}
\mathbf{a}_{1} \\
\mathbf{a}_{2} \\
\mathbf{a}_{3}
\end{array}\right] \sim N\left(0, \mathbf{A} \otimes\left[\begin{array}{ccc}
\sigma_{\mathrm{a} 1}^{2} & \sigma_{\mathrm{a} 1 \mathrm{a} 2} & \sigma_{\mathrm{a} 1 \mathrm{a} 3} \\
& \sigma_{\mathrm{a} 2}^{2} & \sigma_{\mathrm{a} 2 \mathrm{a} 3} \\
& & \sigma_{\mathrm{a} 3}^{2}
\end{array}\right]\right)
$$

and

$$
\left[\begin{array}{l}
\mathbf{e}_{1} \\
\mathbf{e}_{2} \\
\mathbf{e}_{3}
\end{array}\right] \sim N\left(0,\left(\left[\begin{array}{ccc}
\mathbf{I}_{\mathrm{n} 1} \sigma_{\mathrm{e} 1}^{2} & 0 & 0 \\
& \mathbf{I}_{\mathrm{n} 2} \sigma_{\mathrm{e} 2}^{2} & 0 \\
& & \mathbf{I}_{\mathrm{n} 3} \sigma_{\mathrm{e} 3}^{2}
\end{array}\right]\right),\right.
$$

where $\mathbf{A}$ indicates the additive genetic relationships matrix between individuals in the pedigree, $\sigma_{\mathrm{ai}}^{2}$ refers to the additive genetic variance in the ith climatic zone, and $\sigma_{\mathrm{a} 1 \mathrm{a} 2}, \sigma_{\mathrm{a} 1 \mathrm{a} 3}$, and $\sigma_{\mathrm{a} 2 \mathrm{a} 3}$ are the additive genetic covariances between moderate-semi-cold, moderate-cold, and semi-cold-cold zones, respectively. Similarly, $\sigma_{\mathrm{e}}^{2}$ is the residual variance of the ith climate zone, and $\mathbf{I}_{\mathrm{ni}}$ is an identity matrix of size $n_{i} \times n_{i}$ for the residual in the ith climatic zone (where $\mathrm{n}_{\mathrm{i}}$ indicates the number of records in the ith climate). No residual covariance existed among the studied climatic zones, as cows were present only in a single climate. 
Heritability of fertility traits in the ith climate was estimated as

$$
\mathrm{h}_{\mathrm{i}}^{2}=\frac{\sigma_{\mathrm{ai}}^{2}}{\sigma_{\mathrm{ai}}^{2}+\sigma_{\mathrm{ei}}^{2}},
$$

and genetic correlation between climatic zones $\mathrm{i}$ and $\mathrm{j}$ was estimated as

$$
\mathrm{r}_{\mathrm{aij}}=\frac{\sigma_{\mathrm{aiaj}}}{\sigma_{\mathrm{ai}} \times \sigma_{\mathrm{aj}}} .
$$

Both SCS and production traits (milk yield, fat, and protein) were analyzed using multiple-trait random regression test-day model with fourth-order Legendre polynomial. Different random regression coefficients can be used to model the change from the beginning to the end of lactation (Jamrozik et al., 1997). Different orders of Legendre polynomials (from 2 to 5 ) were compared based on the deviance information criterion (DIC). This criterion, developed by Spiegelhalter et al. (2002), has been widely used as a statistical tool for comparing models in a Bayesian framework. The DIC combines the goodness of fit and the degree of parameterization of the model, and can easily be calculated from the samples generated by the Monte Carlo Markov chain. A smaller value of DIC is favored, because it indicates a better fit at a lower degree of model complexity (Bohmanova et al., 2008). The DIC can be described as $\mathrm{DIC}=\overline{\mathrm{D}}(\theta)+\mathrm{P}_{\mathrm{D}}$ (Spiegelhalter et al., 2002), where $\overline{\mathrm{D}}(\theta)$ is the posterior expectation of the Bayesian deviance and $\mathrm{P}_{\mathrm{D}}$ is the effective number of parameters.

For analysis of the SCS and production traits, the following model was applied:

$$
\begin{aligned}
& {\left[\begin{array}{l}
\mathbf{y}_{1} \\
\mathbf{y}_{2} \\
\mathbf{y}_{3}
\end{array}\right]=\left[\begin{array}{ccc}
\mathbf{X}_{1} & 0 & 0 \\
0 & \mathbf{X}_{2} & 0 \\
0 & 0 & \mathbf{X}_{3}
\end{array}\right]\left[\begin{array}{l}
\mathbf{b}_{1} \\
\mathbf{b}_{2} \\
\mathbf{b}_{3}
\end{array}\right]+\left[\begin{array}{ccc}
\mathbf{Z}_{\mathrm{a} 1} & 0 & 0 \\
0 & \mathbf{Z}_{\mathrm{a} 2} & 0 \\
0 & 0 & \mathbf{Z}_{\mathrm{a} 3}
\end{array}\right]\left[\begin{array}{l}
\mathbf{a}_{1} \\
\mathbf{a}_{2} \\
\mathbf{a}_{3}
\end{array}\right]} \\
& +\left[\begin{array}{ccc}
\mathbf{Z}_{\mathrm{p} 1} & 0 & 0 \\
0 & \mathbf{Z}_{\mathrm{p} 2} & 0 \\
0 & 0 & \mathbf{Z}_{\mathrm{p} 3}
\end{array}\right]\left[\begin{array}{l}
\mathbf{p}_{1} \\
\mathbf{p}_{2} \\
\mathbf{p}_{3}
\end{array}\right]+\left[\begin{array}{l}
\mathbf{e}_{1} \\
\mathbf{e}_{2} \\
\mathbf{e}_{3}
\end{array}\right],
\end{aligned}
$$

where $\mathbf{y}_{\mathrm{i}}$ represents the vector of observation for each trait (milk yield, fat, protein, or SCS) in the ith climatic zone, $\mathrm{i} \in(1,2,3)$; $\mathbf{b}$ is the vector of fixed effects of herd-test day and DIM in the ith climate (DIM was considered as a step function that changed every day for the fixed part, and Legendre polynomials were used for the random parts of the model); $\mathbf{a}_{\mathrm{i}}$ and $\mathbf{p}_{\mathrm{i}}$ refer to the vectors of random regressions (intercept, linear, quadratic, cubic, quartic) for the additive genetic and permanent environmental effects in the ith climatic zone, respectively; e is the vector of random residual effect in the ith climatic zone; $\mathbf{Z}_{\mathrm{a}}$ and $\mathbf{Z}_{\mathrm{p}}$ indicate the matrices containing Legendre polynomial coefficients which respectively relate $\mathbf{a}$ and $\mathbf{p}$ to $\mathbf{y}$; and $\mathbf{X}$ is the incidence matrix connecting $\mathbf{b}$ to $\mathbf{y}$.

The prior distribution of the breeding values were defined thus:

$$
\left[\begin{array}{l}
\mathbf{a}_{1} \\
\mathbf{a}_{2} \\
\mathbf{a}_{3}
\end{array}\right] \sim M V N\left(0, \quad \mathbf{A} \otimes \mathbf{G}_{0}\right),
$$

where $\mathbf{A}=$ additive genetic relationship matrix; $\mathbf{G}_{0}$ is a $15 \times 15$ matrix of additive genetic (co)variances; and MVN is multivariate normal. The three $5 \times 5$ diagonal blocks correspond to the variances and covariances within each climatic zone, and the remaining corresponds to the additive genetic covariance between climates; $\otimes$ is the Kronecker product operator. Similarly, prior distribution for the permanent environmental effects was identified as

$$
\left[\begin{array}{l}
\mathbf{p}_{1} \\
\mathbf{p}_{2} \\
\mathbf{p}_{3}
\end{array}\right]=\left[\begin{array}{ccc}
\mathbf{I}_{\mathrm{ic} 1} \otimes \mathbf{P}_{\mathrm{i} 1} & 0 & 0 \\
0 & \mathbf{I}_{\mathrm{ic} 2} \otimes \mathbf{P}_{\mathrm{i} 2} & 0 \\
0 & 0 & \mathbf{I}_{\mathrm{ic} 3} \otimes \mathbf{P}_{\mathrm{i} 3}
\end{array}\right],
$$

where $\mathbf{I}_{\text {ici }}$ is an identity matrix of size $\mathrm{c} \times \mathrm{c}$ for the permanent environment effect in the ith climate $\left(c_{i}\right.$ is the number of cows with records in the ith climate); $\mathbf{P}_{\mathrm{i}}=5 \times 5$ (co)variance matrix of random regression coefficients in the ith climate. Three $\mathbf{P}_{\mathrm{i}}$ diagonal blocks correspond to (co)variance matrices for 3 climate zones, and the remaining were zero because no covariance existed for the permanent environments across climatic zones, because cows were only recorded within a climate.

Heterogeneous residual variances across lactation were assumed as follows:

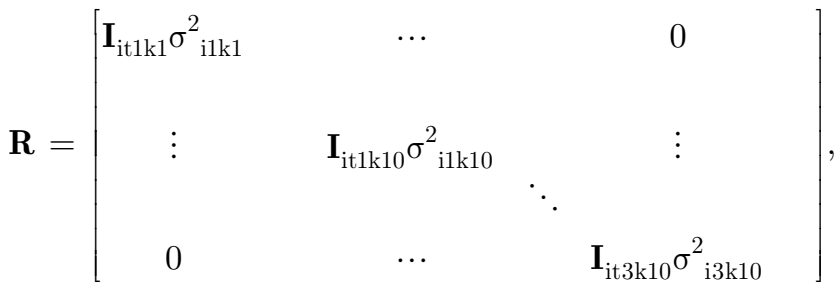


where $\mathbf{I}_{\text {iti }}$ is an identity matrix of size $t \times t$ for the residual effects in the ith climate and kth class of DIM ( $t$ indicates the number of animals with records for the kth class of DIM). The model therefore assumes heterogeneous variances in each of 10 classes of DIM (i.e., 5-30, 31-60, 61-90, 91-120, 121-150, 151-180, 181-210, 211-240, 241-270, 271-305) for each trait. Hence, the model contained a total of 30 different residual variances. (Due to the monthly records, cows in each class have 1 record.)

The prior distributions for all the fixed and all the dispersion parameters in both models ([1] and [2]) were taken as flat.

The additive genetic (co)variance matrix, as a function of DIM, was obtained by $\boldsymbol{\Phi} \mathbf{G}_{0} \boldsymbol{\Phi}^{\prime}$, where $\boldsymbol{\Phi}=$ a 900 $\times 15$ matrix of Legendre polynomial coefficients, and $\mathbf{G}_{0}=$ the $15 \times 15$ matrix of genetic (co)variances as previously defined (Kirkpatrick et al., 1990). The final matrix was a $900 \times 900$ matrix with three $300 \times 300$ blocks of variance matrices in the diagonal and three $300 \times 300$ blocks of covariance matrices in the upper and lower diagonals. Diagonal elements of this (co)variance matrix represent the additive genetic variance $\left(\sigma_{a}^{2}\right)$ for each DIM in each region. The permanent environmental variance matrix was obtained by $\mathbf{\Phi} \mathbf{P}_{0} \boldsymbol{\Phi}^{\prime}$, where $\mathbf{P}_{0}=\operatorname{diag}\left(\mathbf{P}_{1}, \mathbf{P}_{2}, \mathbf{P}_{3}\right)$ was a $15 \times 15$ matrix. Diagonal elements of the permanent environmental variance matrix indicate permanent environmental variances $\left(\sigma_{\mathrm{pe}}^{2}\right)$ for each DIM in each climate. Genetic correlations within and between climates were calculated as the ratio of the genetic covariances between and within these environments to the product of their genetic standard deviations (SD). Genetic correlations between environments were calculated as

$$
r_{g(i, j)}=\frac{G(i, j)}{\sqrt{G(i, i) \times G(j, j)}},
$$

where $G(i, j)$ is the off-diagonal elements of genetic covariance matrix (for SCS and production traits) in the ith and jth climatic zones, and $G(\mathrm{i}, \mathrm{i})$ and $\mathrm{G}(\mathrm{j}, \mathrm{j})$ indicate the diagonals of genetic (co)variance matrices in the ith and jth regions, respectively.

Genetic correlations for the total 305-d production between different climatic zones were calculated following Hammami et al. (2008).

\section{Heritability}

Estimates of $\mathrm{h}_{(\mathrm{ij})}^{2}$ for test days $\mathrm{j}$ in the ith climate were calculated as

$$
\mathrm{h}_{(\mathrm{ij})}^{2}=\frac{\sigma_{\mathrm{a}(\mathrm{ij})}^{2}}{\sigma_{\mathrm{a}(\mathrm{ij})}^{2}+\sigma_{\mathrm{p}(\mathrm{ij})}^{2}+\sigma_{\mathrm{e}(\mathrm{ik})}^{2}},
$$

where $\sigma_{\mathrm{a}(\mathrm{ij})}^{2}$ and $\sigma_{\mathrm{p}(\mathrm{ij})}^{2}$ refer to the additive genetic and the permanent environmental variances for test day $\mathrm{j}$ in climate $\mathrm{i}$, respectively, and $\sigma_{\mathrm{e}(\mathrm{ik})}^{2}$ shows the heterogeneous residual variance for environment $\mathrm{i}$ in DIM class $\mathrm{k}$.

For the SCS and production traits, heritability of $305 \mathrm{~d}$ was calculated by lactation sums of variance and covariance components, thus:

$$
\mathrm{h}_{(305 \mathrm{~d})}^{2}=\frac{\sigma_{\mathrm{a}(305 \mathrm{~d})}^{2}}{\sigma_{\mathrm{a}(305 \mathrm{~d})}^{2}+\sigma_{\mathrm{p}(305 \mathrm{~d})}^{2}+\Sigma \sigma_{\mathrm{e}}^{2}},
$$

where $\Sigma \sigma_{\mathrm{e}}^{2}$ was the sum of residual variances along the lactation. The analyses for all the studied traits were performed under the Bayesian approach, using the DMU package (Madsen and Jensen, 2013). The final chain length was set to 620,000 , with the interleave 200 . The first 20,000 were discarded as burn-in period, and posterior means and SD of parameters were calculated from every 200th sample out of 600,000 samples. Convergence diagnostics for dispersion parameters in the Monte Carlo Markov chain were assessed using the $\mathrm{R}$ package boa (Smith, 2007). Monte Carlo Markov chain standard errors (SE) for posterior means were computed by $\mathrm{SE}=\frac{\mathrm{PSD}}{\sqrt{\mathrm{N}_{\mathrm{e}}}}$, where PSD is the SD of posterior means for heritabilities and genetic correlations, and $\mathrm{N}_{\mathrm{e}}$ is the effective number of posterior samples.

\section{RESULTS}

In the present study, we used data from first-lactation Holstein cows in different climatic zones of Iran to estimate the $\mathrm{G} \times \mathrm{E}$ effect on fertility traits, SCS, and production traits. Furthermore, for the SCS and production traits, we investigated genetic correlation structures within climates for the traits expressed at different test days. For all the studied traits, (co)variance components and heritabilities were estimated for cows in each climatic zone.

\section{Descriptive Statistics}

The overall mean of AFC and CInt were 749 and $397 \mathrm{~d}$, with SD of 72.8 and $67.8 \mathrm{~d}$, respectively (Table 
1). The mean AFC and CInt of the cows were different among climates, with the longest AFC and CInt in semi-cold climate. For SCS we observed the highest mean in the semi-cold and the highest SD in the cold climate. The SCS were 0.162 and 0.126 higher in the semi-cold climate compared with the moderate and cold zones, respectively. For the production traits, cows produced more milk but with the lowest percentages of fat and protein in the moderate climate. The overall mean for SCS, milk yield, fat, and protein were 1.91, $34.7 \mathrm{~kg}, 3.13 \%$, and $2.95 \%$ with SD of $1.56,7.76,1.01$, and 0.62 , respectively.

\section{Variance Components}

Variance components and heritability estimates for fertility traits and the lactation measures of SCS and production traits are given in Table 2. For fertility traits the highest value of genetic variances and heritabilities were observed in cold climate. Also, in all climatic zones, higher permanent variances were observed for SCS and milk yield, compared with the additive genetic variances, which indicates that these traits are more affected by environmental conditions. However, for fat and protein the results were in the opposite direction compared with results obtained for SCS and milk (Table 2).
Moreover, examination of RRM according to DIC indicated the fourth-order Legendre polynomial as the best-fitted model with the lowest DIC. The estimates of variance components and heritabilities for the SCS and production traits over the lactation illustrated heterogeneity for these parameters (Figure 1 and Supplemental Figure S1; https://doi.org/10.6084/m9.figshare .15170487.v3, Atrian et al., 2021).

\section{Fertility}

The additive genetic variances of fertility traits were larger in cold climate compared with moderate climate, ranging from 756 to 925 and from 186 to 209 for AFC and CInt, respectively (Table 2). In contrast, the lowest residual variances were found in the cold region $(3,308$ for AFC and 4,149 for CInt).

\section{Phenotypic and Residual Variances as Function of DIM}

The phenotypic and residual variance curves as a function of DIM are presented in Figure 1 (for SCS and protein content) and Supplemental Figure S1 (for milk yield and fat content).

In all climates, phenotypic variance of SCS was higher in the early lactation, from which it declined

Table 2. Lactation sums for posterior mean of heritability and variance components

\begin{tabular}{|c|c|c|c|c|}
\hline $\begin{array}{l}\text { Trait and } \\
\text { climate zone }^{1}\end{array}$ & Heritability $^{2}$ & $\begin{array}{c}\text { Genetic } \\
\text { variance }\end{array}$ & $\begin{array}{c}\text { Permanent } \\
\text { environmental } \\
\text { variance }\end{array}$ & $\begin{array}{l}\text { Residual } \\
\text { variance }\end{array}$ \\
\hline \multicolumn{5}{|l|}{$\mathrm{AFC}$} \\
\hline Moderate & $0.171 \pm 0.008$ & 756.9 & - & 3,648 \\
\hline Semi-cold & $0.175 \pm 0.007$ & 764.6 & - & 3,582 \\
\hline Cold & $0.218 \pm 0.011$ & 925.1 & - & 3,308 \\
\hline \multicolumn{5}{|l|}{ CInt } \\
\hline Moderate & $0.042 \pm 0.004$ & 186.6 & - & 4,236 \\
\hline Semi-cold & $0.045 \pm 0.003$ & 202.1 & - & 4,266 \\
\hline Cold & $0.048 \pm 0.005$ & 209.3 & - & 4,149 \\
\hline \multicolumn{5}{|l|}{ SCS } \\
\hline Moderate & $0.139 \pm 0.009$ & 2,998 & 18,183 & 275 \\
\hline Semi-cold & $0.159 \pm 0.008$ & 4,188 & 21,684 & 391 \\
\hline Cold & $0.171 \pm 0.008$ & 3,535 & 16,571 & 452 \\
\hline \multicolumn{5}{|l|}{ Milk (kg) } \\
\hline Moderate & $0.378 \pm 0.011$ & 489,531 & 799,115 & 4,099 \\
\hline Semi-cold & $0.365 \pm 0.009$ & 353,956 & 611,189 & 4,417 \\
\hline Cold & $0.353 \pm 0.014$ & 420,839 & 764,286 & 4,607 \\
\hline \multicolumn{5}{|l|}{ Fat $(\%)$} \\
\hline Moderate & $0.624 \pm 0.011$ & 3,568 & 2,029 & 112.5 \\
\hline Semi-cold & $0.593 \pm 0.011$ & 2,795 & 1,770 & 139.9 \\
\hline Cold & $0.639 \pm 0.019$ & 2,034 & 1,024 & 119.5 \\
\hline \multicolumn{5}{|l|}{ Protein (\%) } \\
\hline Moderate & $0.665 \pm 0.009$ & 704 & 339 & 14.75 \\
\hline Semi-cold & $0.681 \pm 0.008$ & 574 & 255 & 13.06 \\
\hline Cold & $0.677 \pm 0.014$ & 474 & 208 & 16.86 \\
\hline
\end{tabular}

${ }^{1} \mathrm{AFC}=$ age at first calving; CInt $=$ calving interval.

${ }^{2}$ Posterior mean \pm posterior SD. 

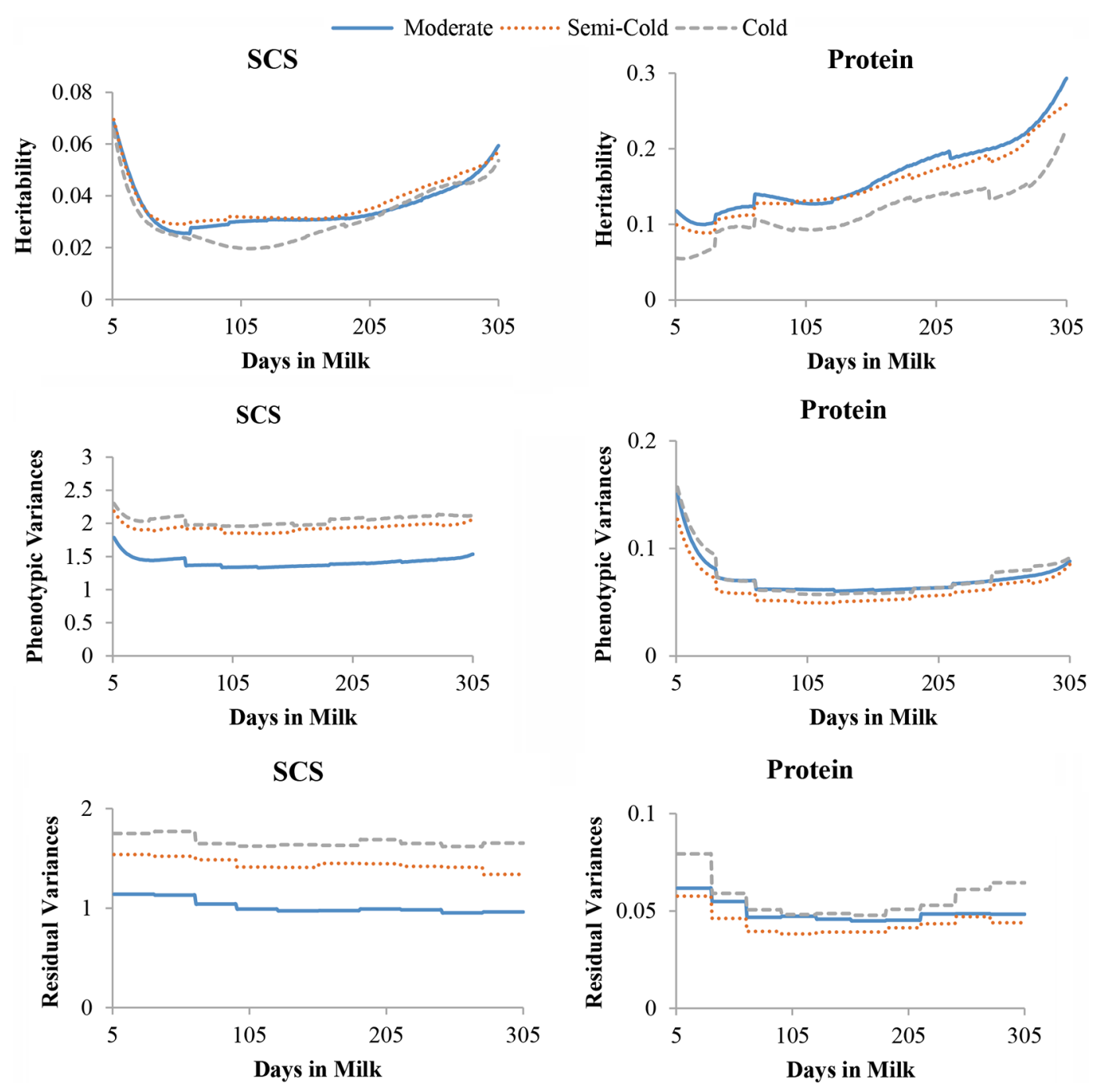

Figure 1. Heritabilities and variance components for SCS and protein (\%) in the moderate (solid line), semi-cold (dotted line), and cold (dashed line) regions.

until the second month, and then remained stable until the end of lactation. Generally, the level of phenotypic variance curve in the moderate climate was lower than that of the cold and semi-cold climates.

For milk yield, the phenotypic variance was greater in the early lactation (first month), followed by a decline until mid-lactation, and then a gradual increase toward the end of lactation, in all climates. Phenotypic variances for fat and protein were highest in the first 10 $\mathrm{d}$ and then were stable until the end of lactation. The level of phenotypic variance for fat was slightly higher in semi-cold climate, whereas it was lower for protein in the same climate.

Residual variance for SCS was larger in early lactation and then decreased until d 68 and was almost stable until the end of lactation. For protein, the largest residual variance was obtained in early and late lacta- tion. The results showed the largest residual variance for other production traits especially in early lactation (details can be found in Supplemental Figure S1).

\section{Heritability Estimates as Function of DIM}

The curves for heritability as function of DIM for SCS and production traits are shown in Figure 1 and Supplemental Figure S1. The heritability curve for SCS showed maximum values in the first $10 \mathrm{~d}$, declined until mid-lactation, and then increased again until the end of lactation. The heritability of protein gradually increased from early lactation, reaching a maximum value on $\mathrm{d} 305$, when it was 0.25 . For other production traits, the level of heritability curve was high in the early and the late lactation (Supplemental Figure S1). 
Table 3. Genetic correlations for fertility traits (AFC, CInt) and 305-d SCS and production traits (milk, fat, and protein) and posterior SD (PSD) across the climatic zones ${ }^{1}$

\begin{tabular}{lcccccc}
\hline Genetic correlation $( \pm$ PSD $)$ & AFC & CInt & SCS & Milk $(\mathrm{kg})$ & Fat $(\%)$ & Protein $(\%)$ \\
\hline Between moderate and semi-cold & $0.909 \pm 0.018$ & $0.942 \pm 0.021$ & $0.884 \pm 0.038$ & $0.957 \pm 0.020$ & $0.935 \pm 0.025$ & $0.948 \pm 0.023$ \\
Between moderate and cold & $0.860 \pm 0.029$ & $0.890 \pm 0.043$ & $0.756 \pm 0.072$ & $0.940 \pm 0.024$ & $0.925 \pm 0.032$ & $0.933 \pm 0.030$ \\
Between semi-cold and cold & $0.858 \pm 0.030$ & $0.914 \pm 0.065$ & $0.764 \pm 0.076$ & $0.927 \pm 0.031$ & $0.932 \pm 0.036$ & $0.934 \pm 0.031$ \\
\hline
\end{tabular}

${ }^{1} \mathrm{AFC}=$ age at first calving; CInt $=$ calving interval. Standard errors of posterior means ranged from 0.0003 to 0.0009 for 305 -d genetic correlation.

\section{Variance Components for Lactation Totals}

Posterior means of the variance components for the lactation sums were obtained from the summed variances and covariances of the $300 \times 300$ matrix for SCS and production traits (Table 2). The results revealed that additive genetic variance of the SCS was higher in the semi-cold region compared with that of the cold and moderate regions (ranging from 2,998 to 4,188). Just like additive genetic variances, the highest environmental variances were observed in the semi-cold climate (ranging from 16,571 to 21,684).

For production traits, the highest genetic variances for lactation sums were found in the moderate climate. Genetic variance ranged from 353,956 to 489,531 for milk yield, from 2,034 to 3,568 for fat, and from 474 to 704 for protein. Similar to additive genetic variances, permanent environmental variances of the production traits were always larger in the moderate climate.

\section{Heritability Estimates}

For both fertility traits, heritability estimates were higher in colder regions due to higher genetic variance and lower residual variance in those regions (Table 2).

For SCS, the highest heritability was observed in the cold climate (0.171), due to lower permanent environmental variances in this climate. The largest genetic variance of this trait was obtained in the semi-cold climate. For the production traits, no significant difference was observed among the regions. The values for heritability ranged from 0.353 to 0.378 for milk yield, from 0.593 to 0.639 for fat, and from 0.665 to 0.681 for protein (Table 2).

\section{Genetic Correlations}

Fertility Traits. Genetic correlation of fertility traits was obtained using the trivariate model [1], assuming records in different climates as different traits (Table $3)$. Genetic correlation ( \pm posterior SD) varied from $0.858( \pm 0.030)$ to $0.909( \pm 0.018)$ for $\mathrm{AFC}$ and from $0.890( \pm 0.043)$ to $0.942( \pm 0.021)$ for CInt. The lowest genetic correlation for AFC was observed between moderate and semi-cold climates, and for CInt between moderate and cold climates. The highest posterior SD for genetic correlation for both traits was observed between semi-cold and cold climates.

Genetic Correlation for 305-D Totals for SCS and Production Traits. In this study, genetic correlations between the SCS trait measured in different climates were generally lower than those obtained for the production traits. For the SCS and production traits, genetic correlations between climates were computed for 305-d sums (Table 3).

Genetic correlations for SCS across climates ranged from 0.756 to 0.884 , with posterior $\mathrm{SD}$ ranging from 0.038 to 0.076 , suggesting the presence of $\mathrm{G} \times \mathrm{E}$ interaction, especially between cold and other climates. For milk yield and fat content, 305-d genetic correlations were close to unity and ranged from 0.927 to 0.957 and from 0.925 to 0.935 , respectively. The highest posterior SD of genetic correlation for protein and fat were observed between semi-cold and cold climates (0.031 and 0.036 , respectively). The genetic correlation for protein was close to unity and ranged from 0.933 to 0.948 , with posterior SD ranging from 0.023 to 0.031 (Table 3).

Genetic Correlation as Function of DIM Between Climates. The curves of genetic correlation of SCS between climates as a function of DIM are presented in Figure 2A. For this trait, the general trend of genetic correlation curve between all climates showed the maximum level during the second and third lactation months and then decreased toward the end of lactation. Also, the lowest genetic correlations were observed in the early and late lactation. Generally, comparison of curves between climates revealed that the genetic correlations between moderate and semi-cold zones were significantly higher than the correlations between the other climates.

For protein, the curve of genetic correlation between climates was the lowest in the beginning and at the end of lactation, and largest in mid-lactation. Additionally, the level of genetic correlation between moderate and semi-cold climates was higher than that of the other climatic zones (Figure 3A). Trends of genetic correlations for fat and milk yield were very similar to that of protein, especially in the early and late lactation; there- 
fore these are shown only in Supplemental Figures S2 and S3 (https://doi.org/10.6084/m9.figshare.15170487 .v3, Atrian et al., 2021).

Genetic Correlation Structure Within Climate Zones. In this research, the structures of genetic correlations between different parts of the lactation curve were investigated within each climatic zone. For easy readability, only correlations between DIM 10, 100, 200, and 300 and all other DIM are shown in the figures. For SCS, the genetic correlations between d 10 and d 300 over all climate zones were low. These values were close to zero in moderate and semi-cold climates, whereas in cold climate it was negative. The curves of d 100 and d 200 showed that the genetic correlation between mid-lactation and early lactation is the lowest (close to zero in the semi-cold region and near to 0.2 in moderate and cold regions; Figure 2B, C, and D). Generally, genetic correlations between distant DIM were lower.
However, this structure was not the same across all climatic zones.

For protein, the structure of genetic correlation within the climatic zones was different during the lactation, with a faster drop in correlation by increasing the distance between DIM in the cold climate. In fact, from the correlation curves of d 10 and d 300 in cold climate, it can be concluded that genetic correlations between early and late lactation were negative. However, their amounts were positive in the moderate and semi-cold climates. Also, considering the correlation curves of $\mathrm{d}$ 100 and d 200, it could be concluded that the structure of genetic correlation between mid- and early lactation in cold climate is slightly lower than those of the moderate and semi-cold zones (Figure 3B, C, and D).

Contrary to the results for protein, which showed the lowest genetic correlation between early and late lactation, for fat the curves of $\mathrm{d} 100$ and d 200 showed the
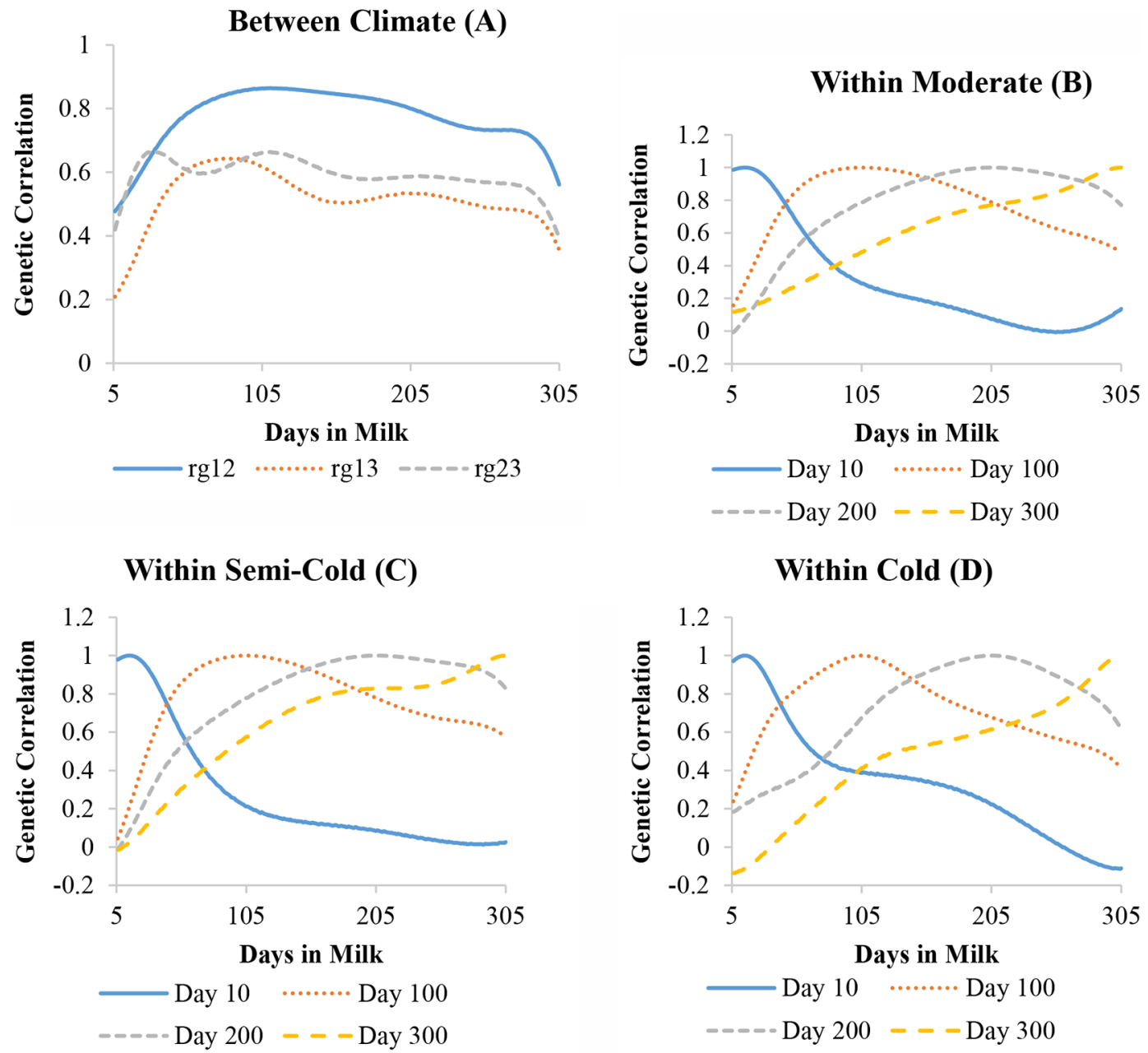

Figure 2. (A) Genetic correlation for SCS between moderate and semi-cold (rg12), moderate and cold (rg13), and semi-cold and cold climates (rg23), and within climatic zones for d 10, 100, 200, and 300 during the lactation curve in moderate (B), semi-cold (C), and cold climates (D). 

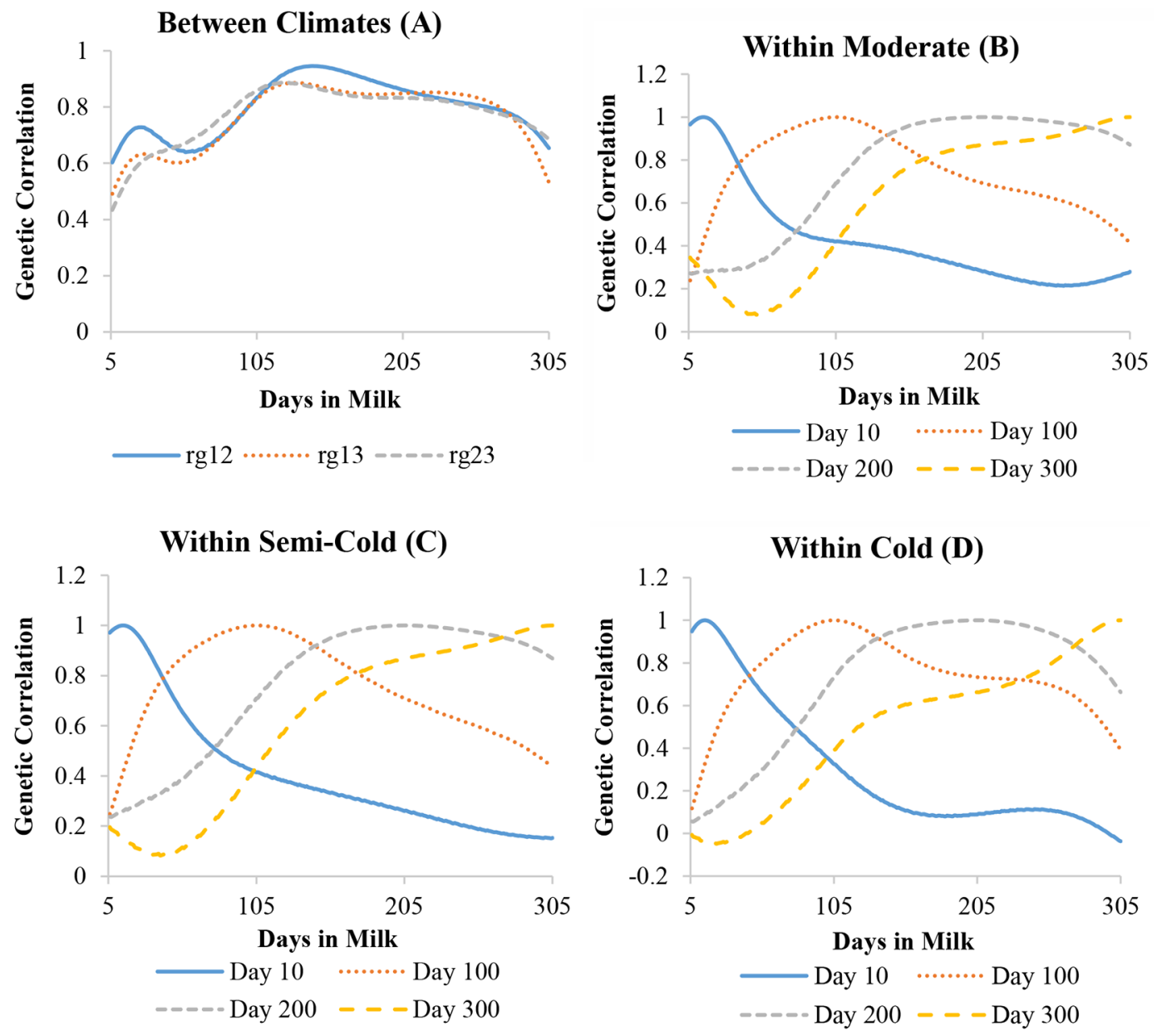

Figure 3. (A) Genetic correlations for protein (\%) between moderate and semi-cold (rg12), moderate and cold (rg13), and semi-cold and cold climatic zones (rg23). Genetic correlation within climatic zones for d 10, 100, 200, and 300 during the lactation curve in the moderate (B), semi-cold (C), and cold climates (D).

lowest genetic correlations between mid- and early lactation, especially in the moderate and semi-cold regions (Supplemental Figure S2B, C, and D; https://doi.org/ 10.6084/m9.figshare.15170487.v3, Atrian et al., 2021).

\section{DISCUSSION}

Iran, as a large country, has quite varied geographical and climatic conditions. For instance, the southern provinces are under very different climatic and management conditions compared with the colder and more humid climate in the northern provinces. The cold climate zone includes mountainous areas with low humidity. Usually, the lowest temperature in this climate occurs in the middle of January, which gradually increases to the maximum temperature in July. The coldness of this area is mainly due to hilly areas with dry weather conditions. The semi-cold climate zone is somewhat intermixed with the other areas and includes several low-lying areas. This zone is mainly affected by periods of warmer winds and, in the coldest periods, reaches $0^{\circ} \mathrm{C}$. The moderate climate is between the lowlying warm climate and the high-altitude cold climate. Temperature of the moderate climate zone during the year ranges between 3 and $28^{\circ} \mathrm{C}$.

In this study, $\mathrm{G} \times \mathrm{E}$ interactions were estimated in the environments that were defined as different climatic zones. Classification of the areas as moderate, semi-cold, and cold were performed based on synoptic weather station data. These climatic zones cover about $47.3 \%$ of the area of Iran, including the major regions for milk production in Iran. Such $\mathrm{G} \times \mathrm{E}$ interactions could also be due to management system differences in various environments (Kearney et al., 2004). For instance, in this research we found the largest average herd size, with highest AFC, in the semi-cold region. 
Differences in AFC might be related to the genetic background of animals as well as to the management system (Brzáková et al., 2020).

The mean AFC and CInt illustrated better fertility performance in colder climates. For SCS, the highest mean was observed in the semi-cold climate. For the production traits, the greatest milk production was observed in the moderate climate, whereas for protein and fat, the lowest values were obtained in this climate.

\section{Variance Components and Heritability}

The lowest genetic variances, as well as the lowest heritability for AFC and CInt, were obtained under the moderate climate. Our results were in agreement with the results of Ravagnolo and Misztal (2002), who reported low heritability of fertility traits when heat stress level were high, considering THI as the indicator for climate. Our estimates of heritability for AFC were close to the results obtained for US dairy cows (Ruiz-Sánchez et al., 2007) and higher than other results reported for Canadian and US Holsteins (Jamrozik et al., 2005; Cole and Null, 2010). Heritability of CInt ranged from 0.042 to 0.048 across the climatic zones, which was close to the results reported by Haile-Mariam et al. (2003) and Jorjani (2006). These differences in heritability among various studies might be related to differences in herd reproduction management, climate, statistical models, and recording practices for these traits in different countries. For SCS and the production traits, we observed heterogeneity in all variance components, both across climatic zones and during the lactation. Generally, heterogeneity of variances can occur in all variance components (i.e., additive genetic, permanent environment, and residual variances), and therefore the estimated heritability is not expected to be constant during lactation (Jensen, 2001). For instance, the residual variance can be heterogeneous during lactation, and various studies have shown higher residual variances at the lactation extremes (López-Romero et al., 2003). In the present study, higher residual variances were observed for all the studied traits in early and late lactation (Figure 1). This could be due to lack of information on effects such as body condition at calving, stage of pregnancy, characteristics of the dry period, and more, which were ignored in the evaluation models (López-Romero et al., 2003). The report by Aliloo et al. (2014) indicated that considering heterogeneity of variances can increase accuracy of predicted breeding values and subsequently affects genetic gain in the population.

In our study, for SCS and production traits, the highest environmental variances were observed at the periphery of lactation (results not shown), which confirms the results of Van Vleck and Henderson (1961), which indicated higher temporary environmental variations at the lactation extremes compared with mid-lactation. This is because mid-lactation is more influenced by genetic and permanent environmental differences among animals. Furthermore, decreasing permanent environmental effects in early lactation is well documented in many studies for milk yield and SCS (Haile-Mariam et al., 2001; Ødegard et al., 2003; Rzewuska et al., 2011; Abdullahpour et al., 2013). In many studies, higher genetic variances are reported in early lactation and toward the end of lactation (Ptak et al., 2007; Rzewuska et al., 2011; Bohlouli et al., 2014). Several studies have reported that different orders of Legendre polynomials could influence estimated variance components especially in the early and toward the end of lactation (Strabel et al., 2005).

Similarly, for SCS and production traits, we observed the highest phenotypic variances in early lactation, followed by a decline toward mid-lactation (Figure 1). Comparable heritability estimates have previously been reported for the Iranian Holstein population (Dadpasand et al., 2013; Kheirabadi, 2018). The trajectory of estimated heritability for SCS in our study was similar to reports by Ptak et al. (2007). However, estimated heritability in their study ranged from 0.11 to 0.22 , which is higher than our estimates. Similarly, Bohmanova et al. (2008) and Samoré et al. (2008) reported higher heritabilities compared with our results.

The trajectory of heritability over lactation for the production traits, especially for milk yield and fat, were similar to the results reported by Bohlouli et al. (2014), who also observed the lowest heritability in early lactation among Iranian Holsteins. However, our results were higher than the results of a previously mentioned study in Iranian Holsteins (Abdullahpour et al., 2013). Differences in results might be related to the data structure. For instance, the heritabilities estimated in one herd are higher than the heritabilities estimated in a wider environment such as a province. Furthermore, the lack of information on effects such as feeding systems, management systems, and specific climatic conditions could lead to different results. Not including these parameters in the model of evaluation can increase the residual variance and consequently result in lower heritability estimates (Abdullahpour et al., 2013).

\section{Genetic Correlations}

Large genetic correlations were observed for AFC and CInt between the climatic zones, which indicates similar ranking of cows for the reproduction traits across the studied climates. Hence, according to our results, re-ranking of animals between climates was not 
important for the fertility traits. However, higher genetic variances and lower residual variances in the cold climate confirmed that the reaction of fertility traits to the environmental factors are less than in the moderate and semi-cold regions. These results showed that, in moderate and semi-cold, animals are more affected by environmental factors such as climatic conditions and management systems. Therefore, selection of animals in these climates maybe is not due to the superior genetics of cows and can create a bias in selection of animals in these climates unless heterogeneity is accounted for in models for genetic evaluation.

Genetic correlations between SCS and production traits in different climatic zones were estimated using an RRM (Model [2]). One application of RRM is the study of $\mathrm{G} \times \mathrm{E}$ interaction as well as investigation of environmental parameters, during lactation. Generally, $\mathrm{G} \times \mathrm{E}$ interactions could be determined by estimating genetic correlations of the same trait in different environments as different traits. Investigation of genetic correlation can be an indication of $\mathrm{G} \times \mathrm{E}$ interaction between environments (Robertson, 1959) and is statistically significant if the genetic correlation is significantly different from unity.

In the current study, genetic correlations of SCS between the cold and the other climatic zones (semi-cold and moderate) were low, especially in early and late lactation. The lowest genetic correlations between testday records were observed in the cold climate, especially in d 10 and 300, which had negative correlations with the early and late lactation, respectively. Genetic correlations of milk yield, protein, and fat between climatic zones were also low in the beginning and toward the end of lactation. The lowest genetic correlations were observed between the cold and the other regions. The within-climate genetic correlations for protein were the lowest along DIM, especially between early and late lactation; whereas for milk and fat the lowest genetic correlations between the beginning and the end of lactation were observed in the moderate and semi-cold climates.

As mentioned earlier, negative genetic correlations were observed between very early and late parts of the lactation. This is in agreement with previously published reports (Searle, 1961; Jamrozik and Schaeffer, 1997; Kettunen et al., 2000). These negative genetic correlations might be due to some peculiar problems in the data analyzed. For instance, in our data, calving date generally appeared $5 \mathrm{~d}$ before the first records. These problems can affect estimation of variance components, especially in the early lactation. Although results of the bivariate models were in agreement with the results of RRM, correlations among specific lactation periods, estimated by bivariate models, were generally higher than those of the RRM. For instance, RRM presented lower genetic correlations for SCS between d 300 and the early lactation as well as for d 10 and the end of lactation. Similarly, the correlations obtained using a bivariate model showed the least values in these parts of the lactation curve for milk yield, fat, and protein (results not shown).

The results of this research demonstrate that the correlation structure is not the same between different environments. Generally, when the genetic correlation is substantially less than 1.0, ranking of genotypes in different environments is considerably different, so that prediction of genetic potential in one environment is not a reliable predictor for other environments (Cromie et al., 1998). Therefore, according to our results, $\mathrm{G} \times \mathrm{E}$ interactions were more important for SCS between cold and the other climatic zones. Also, the within-lactation correlation structure was different in the cold compared with the moderate and semi-cold climates. The effect of $\mathrm{G} \times \mathrm{E}$ interaction on re-ranking of animals is well documented in various studies. According to Carabaño et al. (2016), animals in more temperate climates and semi-extensive grazing systems present heat stress at lower heat loads. In addition, in their study, more re-ranking of animals was performed across the THI scale than the animals in warmer climate and intensive indoor systems. Santana et al. (2016) reported genetic correlations significantly less than unity for milk yield between the comfort and heat-stress zones during periods with extreme values of THI. They suggested that G $\times$ E interaction due to heat stress should be considered in the genetic evaluation. Thus, different selection decisions are necessary when the genetic correlations of traits between various environments are low, because the genetic evaluation and the response of animals to selection are variable at different environments (Santana Jr. et al., 2012). Although we have focused on climatic conditions, other environmental factors such as different management system (feeding, labor, production costs, and more) can affect the estimated genetic correlation. In fact, genetic correlations could be lower among environments with very different management systems (Kearney et al., 2004). As a result, when utilizing artificial insemination of selected sires in a country like Iran, with very variable geographical and climatic conditions and management systems, neglecting $\mathrm{G} \times \mathrm{E}$ interactions can have negative impacts on genetic improvement and economic benefit of selection schemes, especially for SCS.

\section{CONCLUSIONS}

Generally, $\mathrm{G} \times \mathrm{E}$ interactions were low for $\mathrm{AFC}$ and CInt. Genetic correlations between climatic zones for 
these traits ranged from 0.858 to 0.942 . Stronger $\mathrm{G} \times \mathrm{E}$ interactions, ranging from 0.756 to 0.884 , were observed for SCS, especially between cold and the other climates. Also, for production traits, genetic correlations among climates were high and close to unity. Genetic correlations along DIM within each climate were different for all the studied traits. Our results showed the lowest genetic correlations between early and late lactation in the cold climate for SCS and protein content, whereas for the milk yield and fat percentage during this period, the lowest genetic correlations were observed in the moderate and semi-cold climates. Therefore, the results suggest that the effect of $\mathrm{G} \times \mathrm{E}$ interaction should be considered for genetic evaluation of animals for SCS across climatic zones. In many countries like Iran, there is currently no information about clinical mastitis. Considering the available information on SCS in Iran, and due to its strong genetic correlation with clinical mastitis, our finding about $\mathrm{G} \times \mathrm{E}$ interaction could be useful in genetic selection of animals for resistance to mastitis, which are differently ranked across various climatic zones.

\section{ACKNOWLEDGMENTS}

The authors have not stated any conflicts of interest.

\section{REFERENCES}

Abdullahpour, R., M. M. Shahrbabak, A. Nejati-Javaremi, R. V. Torshizi, and R. Mrode. 2013. Genetic analysis of milk yield, fat and protein content in Holstein dairy cows in Iran: Legendre polynomials random regression model applied. Arch. Tierzucht 56:497-508. https://doi.org/10.7482/0003-9438-56-048.

Aliloo, H., S. Miraie-Ashtiani, M. Moradi Shahrbabak, J. Urioste, and M. Sadeghi. 2014. Accounting for heterogeneity of phenotypic variance in Iranian Holstein test-day milk yield records. Livest. Sci. 167:25-32. https://doi.org/10.1016/j.livsci.2014.05.012.

Atrian, F., and H. Jensen. Gao, S. Joezy-Shekalgorabi, P. Madsen, M. Amin-Afshar, S. Ali, and J. Jensen. 2021. Heritability and genetic correlation. figshare. Figure. https://doi.org/https://doi.org/10 .6084/m9.figshare.15170487.v3.

Bohlouli, M., J. Shodja, S. Alijani, and N. Pirany. 2014. Interaction between genotype and geographical region for milk production traits of Iranian Holstein dairy cattle. Livest. Sci. 169:1-9. https:/ /doi.org/10.1016/j.livsci.2014.08.010.

Bohmanova, J., F. Miglior, J. Jamrozik, I. Misztal, and P. Sullivan. 2008. Comparison of random regression models with Legendre polynomials and linear splines for production traits and somatic cell score of Canadian Holstein cows. J. Dairy Sci. 91:3627-3638. https://doi.org/10.3168/jds.2007-0945.

Boonkum, W., I. Misztal, M. Duangjinda, V. Pattarajinda, S. Tumwasorn, and S. Buaban. 2011. Genetic effects of heat stress on days open for Thai Holstein crossbreds. J. Dairy Sci. 94:1592-1596. https://doi.org/10.3168/jds.2010-3491.

Bouraoui, R., M. Lahmar, A. Majdoub, M. Djemali, and R. Belyea. 2002. The relationship of temperature-humidity index with milk production of dairy cows in a Mediterranean climate. Anim. Res. 51:479-491. https://doi.org/10.1051/animres:2002036.

Brzáková, M., J. Čítek, A. Svitáková, Z. Veselá, and L. Vostrý. 2020. Genetic parameters for age at first calving and first calving in- terval of beef cattle. Animals (Basel) 10:2122. https://doi.org/10 $.3390 /$ ani10112122.

Carabaño, M. J., B. Logar, J. Bormann, J. Minet, M. L. Vanrobays, C. Díaz, B. Tychon, N. Gengler, and H. Hammami. 2016. Modeling heat stress under different environmental conditions. J. Dairy Sci. 99:3798-3814. https://doi.org/10.3168/jds.2015-10212.

Cerón-Muñoz, M. F., H. Tonhati, C. N. Costa, J. Maldonado-Estrada, and D. Rojas-Sarmiento. 2004. Genotypex environment interaction for age at first calving in Brazilian and Colombian Holsteins. J. Dairy Sci. 87:2455-2458. https://doi.org/10.3168/jds.S0022 -0302(04)73369-X.

Cole, J., and D. Null. 2010. Age at first calving in Holstein cattle in the United States. J. Dairy Sci. 93:594.

Cromie, A. R., D. Kelleher, F. Gordon, and M. Rath. 1998. Genotype by environment interaction for milk production traits in Holstein Friesian dairy cattle in Ireland. Interbull Bull. 15:100-104.

Dadpasand, M., S. R. Miraei-Ashtiani, M. Moradi Shahrebabak, and R. Vaez Torshizi. 2008. Impact of conformation traits on functional longevity of Holstein cattle of Iran assessed by a Weibull proportional hazards model. Livest. Sci. 118:204-211. https://doi .org/10.1016/j.livsci.2008.01.024.

Dadpasand, M., M. Zamiri, and H. Atashi. 2013. Genetic correlation of average somatic cell score at different stages of lactation with milk yield and composition in Holstein cows. Iran. J. Vet. Res. 14:190-196. https://doi.org/10.22099/ijvr.2013.1680.

Falconer, D., and T. Mackay. 1996. Introduction to Quantitative Genetics. 4th ed. Longman Group.

Ghiasi, H., A. Pakdel, A. Nejati-Javaremi, H. Mehrabani-Yeganeh, M. Honarvar, O. González-Recio, M. J. Carabaño, and R. Alenda. 2011. Genetic variance components for female fertility in Iranian Holstein cows. Livest. Sci. 139:277-280. https://doi.org/10.1016/j livsci.2011.01.020

Haile-Mariam, M., P. Bowman, and M. Goddard. 2003. Genetic and environmental relationship among calving interval, survival, persistency of milk yield and somatic cell count in dairy cattle. Livest. Prod. Sci. 80:189-200. https://doi.org/10.1016/S0301 $-6226(02) 00188-4$.

Haile-Mariam, M., M. Goddard, and P. Bowman. 2001. Estimates of genetic parameters for daily somatic cell count of Australian dairy cattle. J. Dairy Sci. 84:1255-1264. https://doi.org/10.3168/jds .S0022-0302(01)74587-0.

Hammami, H., B. Rekik, H. Soyeurt, C. Bastin, J. Stoll, and N. Gengler. 2008. Genotypex environment interaction for milk yield in Holsteins using Luxembourg and Tunisian populations. J. Dairy Sci. 91:3661-3671. https://doi.org/10.3168/jds.2008-1147.

Hayes, B. J., M. Carrick, P. Bowman, and M. E. Goddard. 2003. Genotype $\times$ environment interaction for milk production of daughters of Australian dairy sires from test-day records. J. Dairy Sci. 86:37363744. https://doi.org/10.3168/jds.S0022-0302(03)73980-0.

Hossein-Zadeh, N. G., A. Nejati-Javaremi, S. Miraei-Ashtiani, and H. Kohram. 2008. An observational analysis of twin births, calf stillbirth, calf sex ratio, and abortion in Iranian Holsteins. J. Dairy Sci. 91:4198-4205. https://doi.org/10.3168/jds.2008-1079.

Huang, C., S. Tsuruta, J. K. Bertrand, I. Misztal, T. J. Lawlor, and J. S. Clay. 2008. Environmental effects on conception rates of Holsteins in New York and Georgia. J. Dairy Sci. 91:818-825. https:/ /doi.org/10.3168/jds.2007-0306.

Ismael, A., E. Strandberg, B. Berglund, M. Kargo, A. Fogh, and P. Løvendahl. 2016. Genotype by environment interaction for the interval from calving to first insemination with regard to calving month and geographic location in Holstein cows in Denmark and Sweden. J. Dairy Sci. 99:5498-5507. https://doi.org/10.3168/jds $2015-10820$

Jamrozik, J., J. Fatehi, and L. Schaeffer. 2005. Models for fertility traits with random herd-year effect: Estimates of genetic parameters for Holsteins. Page 6 in Proc. Dairy Cattle Breeding and Genetics Committee Meeting, University of Guelph, ON, Canada. Research Report to the GEB.

Jamrozik, J., and L. Schaeffer. 1997. Estimates of genetic parameters for a test day model with random regressions for yield traits of 
first lactation Holsteins. J. Dairy Sci. 80:762-770. https://doi.org/ 10.3168/jds.S0022-0302(97)75996-4.

Jamrozik, J., L. Schaeffer, and J Dekkers.. 1997. Genetic evaluation of dairy cattle using test day yields and random regression model. J. Dairy Sci. 80:1217-1226.

Jensen, J. 2001. Genetic evaluation of dairy cattle using test-day models. J. Dairy Sci. 84:2803-2812. https://doi.org/10.3168/jds.S0022 -0302(01)74736-4.

Jorjani, H. 2006. International genetic evaluation for female fertility traits. Interbull Bull. 34:57.

Kearney, J. F., M. M. Schutz, and P. J. Boettcher. 2004. Genotype× environment interaction for grazing vs. confinement. II. Health and reproduction traits. J. Dairy Sci. 87:510-516. https://doi.org/ 10.3168/jds.S0022-0302(04)73190-2.

Kettunen, A., E. A. Mäntysaari, and J. Pösö. 2000. Estimation of genetic parameters for daily milk yield of primiparous Ayrshire cows by random regression test-day models. Livest. Prod. Sci. 66:251261. https://doi.org/10.1016/S0301-6226(00)00166-4.

Kheirabadi, K. 2018. Bayesian analysis of random regression models to model test-day somatic cell score of primiparous Holstein cattle in Iran. J. App. Animal Res. 46:677-684. https://doi.org/10.1080/ 09712119.2017.1386107.

Kirkpatrick, M., D. Lofsvold, and M. Bulmer. 1990. Analysis of the inheritance, selection and evolution of growth trajectories. Genetics 124:979-993. https://doi.org/10.1093/genetics/124.4.979.

Lambertz, C., C. Sanker, and M. Gauly. 2014. Climatic effects on milk production traits and somatic cell score in lactating Holstein-Friesian cows in different housing systems. J. Dairy Sci. 97:319-329. https://doi.org/10.3168/jds.2013-7217.

López-Romero, P., R. Rekaya, and M. Carabaño. 2003. Assessment of homogeneity vs. heterogeneity of residual variance in random regression test-day models in a Bayesian analysis. J. Dairy Sci. 86:3374-3385. https://doi.org/10.3168/jds.S0022-0302(03)73941 -1 .

Madsen, P., and J. Jensen. 2013. A User's Guide to DMU: A Package for Analysing Multivariate Mixed Models. Version 6, Release 5.2. 2013. http://dmu.agrsci.dk/DMU/Doc/Current/dmuv6_guide.5.2 .pdf.

Montaldo, H. H., A. Pelcastre-Cruz, H. Castillo-Juárez, F. J. RuizLópez, and F. Miglior. 2017. Genotype $\times$ environment interaction for fertility and milk yield traits in Canadian, Mexican and US Holstein cattle. Span. J. Agric. Res. 15:e0402. https://doi.org/10 $.5424 / \mathrm{sjar} / 2017152-10317$.

Ødegard, J., J. Jensen, G. Klemetsdal, P. Madsen, and B. Heringstad. 2003. Genetic analysis of somatic cell score in Norwegian cattle using random regression test-day models. J. Dairy Sci. 86:4103-4114. https://doi.org/10.3168/jds.S0022-0302(03)74024-7.

Ptak, E., P. Brzozowski, W. Jagusiak, and K. Zdziarski. 2007. Genetic parameters for somatic cell score for Polish Black-and-White cattle estimated with a random regression model. J. Anim. Feed Sci. 16:357-369. https://doi.org/10.22358/jafs/66757/2007.

Rahbar, R., M. Aminafshar, R. Abdullahpour, and M. Chamani. 2016. Genetic analysis of fertility traits of Holstein dairy cattle in warm and temperate climate. Acta Sci. Anim. Sci. 38:333-340. https:// doi.org/10.4025/actascianimsci.v38i3.31377.

Ravagnolo, O., and I. Misztal. 2000. Genetic component of heat stress in dairy cattle, parameter estimation. J. Dairy Sci. 83:2126-2130. https://doi.org/10.3168/jds.S0022-0302(00)75095-8.

Ravagnolo, O., and I. Misztal. 2002. Effect of heat stress on nonreturn rate in Holstein cows: Genetic analyses. J. Dairy Sci. 85:30923100. https://doi.org/10.3168/jds.S0022-0302(02)74396-8.
Robertson, A. 1959. The sampling variance of the genetic correlation coefficient. Biometrics 15:469-485. https://doi.org/10.2307/ 2527750

Ruiz-Sánchez, R., R. Blake, H. Castro-Gámez, F. Sánchez, H. Montaldo, and H. Castillo-Juárez. 2007. Changes in the association between milk yield and age at first calving in Holstein cows with herd environment level for milk yield. J. Dairy Sci. 90:4830-4834. https: //doi.org/10.3168/jds.2007-0156.

Rzewuska, K., J. Jamrozik, A. Żarnecki, and T. Strabel. 2011. Genetic parameters of test-day somatic cell scores for the first three lactations of Polish Holstein-Friesian cattle. Czech J. Anim. Sci. 56:381-389. https://doi.org/10.17221/1288-CJAS.

Samoré, A. B., A. F. Groen, P. J. Boettcher, J. Jamrozik, F. Canavesi, and A. Bagnato. 2008. Genetic correlation patterns between somatic cell score and protein yield in the Italian Holstein-Friesian population. J. Dairy Sci. 91:4013-4021. https://doi.org/10.3168/ jds.2007-0718.

Santana, M. Jr., J. P. Eler, F. F. Cardoso, L. G. Albuquerque, A. B. Bignardi, and J. B. S. Ferraz. 2012. Genotype by environment interaction for birth and weaning weights of composite beef cattle in different regions of Brazil. Livest. Sci. 149:242-249. https://doi .org/10.1016/j.livsci.2012.07.017.

Santana, M. L., A. B. Bignardi, R. J. Pereira, A. Menéndez-Buxadera, and L. El Faro. 2016. Random regression models to account for the effect of genotype by environment interaction due to heat stress on the milk yield of Holstein cows under tropical conditions. J. App. Genetics 57:119-127. https://doi.org/10.1007/s13353-015-0301-x.

Santana, M. L. Jr., R. J. Pereira, A. B. Bignardi, L. El Faro, M. F. Pires, R. G. Andrade, B. C. Perez, F. A. Bruneli, and M. G. Peixoto. 2019. Dual-purpose Guzerá cattle exhibit high dairy performance under heat stress. J. Anim. Breed. Genet. https://doi .org/10.1111/jbg.12450.

Schaeffer, L. 2004. Application of random regression models in animal breeding. Livest. Prod. Sci. 86:35-45. https://doi.org/10.1016/ S0301-6226(03)00151-9.

Searle, S. 1961. Part lactations. II. Genetic and phenotypic studies of monthly milk fat yield. J. Dairy Sci. 44:282-295. https://doi.org/ 10.3168/jds.S0022-0302(61)89733-6.

Smith, B. J. 2007. boa: An R package for MCMC output convergence assessment and posterior inference. J. Stat. Softw. 21:1-37. https: //doi.org/10.18637/jss.v021.i11.

Spiegelhalter, D. J., N. G. Best, B. P. Carlin, and A. Van Der Linde. 2002. Bayesian measures of model complexity and fit. J. R. Stat. Soc. B 64:583-639. https://doi.org/10.1111/1467-9868.00353.

Strabel, T., J. Szyda, E. Ptak, and J. Jamrozik. 2005. Comparison of random regression test-day models for Polish Black and White cattle. J. Dairy Sci. 88:3688-3699. https://doi.org/10.3168/jds .S0022-0302(05)73055-1.

Valencia, M., H. Montaldo, and F. Ruíz. 2008. Interaction between genotype and geographic region for milk production in Mexican Holstein cattle. Arch. Zootec. 57:457-463.

Van Vleck, L., and C. Henderson. 1961. Estimates of genetic parameters of some functions of part lactation milk records. J. Dairy Sci 44:1073-1084. https://doi.org/10.3168/jds.S0022-0302(61)89858 -5 .

Villalobos, N. L., D. Garrick, and C. Holmes. 2001. Effects of importing semen of Holstein, Holstein-Friesian and Jersey bulls on the future profitability of an Argentine dairy farm. Arch. Zootec. 50:1. 